\title{
LEARNING MANAGEMENT OF ISLAMIC CLASSIC BOOKS: A CASE STUDY AT ASY SIFA ISLAMIC BOARDING SCHOOL
}

\author{
Muhamad Syara Nurhakim ${ }^{(1)}$, Asep Budi(2) \\ Sekolah Tinggi Agama Islam Syekh Manshur \\ Jalan Raya Labuan Km 5 Kadulisung Pandeglang \\ Ponsel : $087772529181^{(1)}, 081310923935^{(2)}$ \\ Surel: syaranurhakim@gmail.com ${ }^{(1)}$, asep.budi@rocketmail.com ${ }^{(2)}$
}

\begin{abstract}
This research is motivated by the lack of learning methods applied to the yellow book learning. The purpose of this study is to determine the planning, implementation, and evaluation of the Islamic classic book, known also as Kitab Kuning. The research method used a qualitative research method. The data collection techniques used observation analysis, interview, and documentation study. The results of the research based on direct observation, documentation and interviews with clerics, teaching boards, administrative staff and santri administrators can be summarized as follows: Planning for learning the Islamic classic book at Pondok Asy Syifa is rooted in kiyai's thinking about the Islamic classic book learning levels due to the absence of a clear lesson plan at the Pondok Asy Syifa. Salafiyah are rooted in the abilities of the santris (students) themselves. The teaching and learning process is carried out every day except Thursday and Friday, the learning of the Islamic classic book is carried out by the teacher/ustadz delivering the subject matter using the method of delivering sorogan, bandongan and rote material. Learning evaluation uses formative evaluation, namely an assessment in the form of nadhaman memorization that is carried out before learning takes place and summative evaluation.
\end{abstract}

Keywords: learning management, Islamic classic book

Submitted: 27 February $2021 \quad$ Revised: 28 March $2021 \quad$ Accepted: 31 March 2021

\section{PENDAHULUAN}

Pendidikan merupakan sebuah usaha yang diajalankan dalam rangka pembentukan karakter, moralitas dan nilai intelektual pada manusia sehingga dalam menjalankan hidupnya akan lebih terarah dan terukur. Dalam Undang-Undang No. 20 Tahun 2003 dikatakan bahwa pendidikan merupakan usaha sadar dan terencana upaya mewujudkan suasana belajardan pembelajaran agar secara aktif peserta didik mengembangkan potensidirinya. Pendidikan sendiri terbagi menjadi tiga bagian yaitu: pendidikan formal, non formal dan informal. Pesantren merupakan sebuah lembaga pendidikan non formal, pesantren merupakan sebuah lembaga di bawah bimbingan guru yang lebih dikenal dengan sebuatan Kiai dan mempunyai asrama untuk tempat menginap santri. Santri tersebut berada dalam kompleks yang juga menyediakan masjid untuk beribadah, 
ruang untuk belajar dan kegiatan keagamaan lainnya. Pesantren adalah lembaga pendidikan Islam yang tumbuh didalam masyarakat Indonesia untuk melayani berbagai kebutuhan dari masyarakat (Madjid, 1984: 18).

Pesantren mengambarkan sebuah kehidupan yang unik, para santri tidak hanya diajarkan ilmu agama saja melainkan bagaimana cara hidup dalam bermasyarakat kelak dan mepersiapkan untuk memenuhi kebutuhan umat khususnya dalam bidang ilmu agama. Pesantren mengajarkan kepada para santri untuk saling peduli terhadap sesama serta menghindari sifat-sifat yang tidak terpuji yang nanti pada akhirnya akan merugikan santri itu sendiri.

Pondok pesantren sebaiknya memiliki standar kompetensi pengajian kitab yang maksudnya adalah kitab standar yang mesti dikuasai oleh santri. standar kompetensi biasanya ini tercermin pada penggunaan kitab-kitab berurutan dari mulai yang ringan sampai yang berat dari kitab yang tipis sampai kitab yang berjilid-jilid. Kitab-kitab digunakan tersebut biasanya disebut kitab kuning (kitab salaf) (Departemen Agama, 2003: $50)$.

Manajemen berasal dari kata "to manage" yang berarti mengatur, mengurus, atau mengelola. Dari arti tersebut, secara substantif, makna manajemen mengandung unsur-unsur kegiatan yang bersifat pengelolaan (Maisah, 2013:10). Manajemen merupakan proses mengorganisasikan atau mengatur terhadap jalannya roda organisasi tersebut. Manajemen yang digunakan dalam sebuah lembaga pendidikan haruslah sesuai dengan perencanaan yang sudah ditetapkan oleh para pemangku kebijakan dalam lembaga tersebut.

Dalam manajemen pembelajaran haruslah mengacu pada pola manajerial umum yang diawali dengan perencanaan dan diakhiri evaluasi, sedangkan pondok pesantren salafiyyah yang bercorak mono manajerial dalam segala hal nya termasuk dalam pembelajaran kitab kuningnya yang menjadikan pembelajaran kitab di pondok pesantren hanya berlangsung alamiah. Manajemen pembelajaran kitab kuning yang diterapkan di pondok pesantren Asy Syifa yang pada faktanya adalah pondok pesantren yang masih menjaga tradisi 
salafiyyah serta belum secara detail menerapkan pola manajemen pembelajaran kitab kuning dengan sistematis. Penelitian terdahulu terkait isu yang diangkat dalam riset ini seperti dari Rahman (2012) yang fokus terhadap manajemen pembelajaran kitab kuning di Pondok Pesanten Al-Falah Banjarbaru.Tentu saja, masalah yang dikaji dalam riset ini diharapkan dapat menambah khazanah perkembangan ilmu pengetahuan yang fokus pada manajemen pembelajaran di pondok pesantren.

Adapun rumusan masalah dalam penelitian ini adalah: Bagaiaman manajemen pembelajaran kitab kuning di Pondok Pesantren Asy-Syifa Saruni Pandeglang?, bagaimana rencana pembelajaran kitab kuning di Pondok Pesantren Asy-Syifa Saruni Pandeglang?, bagaimana pelaksanaaan pembelajaran kitab kuning di Pondok Pesantren Asy-Syifa Saruni Pandeglang?

Adapun tujuan dari penelitian ini adalah : untuk mengetahui manajemen pembelajaran kitab kuning di Pondok Pesantren Asy-Syifa Saruni Pandeglang. Untuk mengetahui rencana pembelajaran kitab kuning di Pondok Pesantren Asy-Syifa Saruni Pandeglang. Untuk mengetahui pelaksanaan pembelajaran kitab kuning di Pondok Pesantren Asy-Syifa Saruni Pandeglang.

\section{KAJIAN TEORETIK}

Menurut Terry dalam Haerana (2016:2) manajemen adalah proses perencanaan, pengorganisasisan, penggerakan dan pengawasan. Dalam rangka usaha mencapai tujuan yang telah dilakukan oleh orang secara bersama-sama, maka jelas diantara mereka itu terdiri atas sekurang-kurangnya dua golongan orang, yakni golongan yang dipimpin dan golongan yang memimpin. Manajemen merupakan proses perencanaan, pengorganisasian, dan penggunaan sumber daya organisasi lainnya agar mencapai tujuan organisasi yang telah dicapainya (Badrudin 2013:3).

Menurut Maharani dalam jurnal yang berjudul manajemen pembelajaran pondok pesantren, bahwa pengertian belajar menurut Huda (2010:84) adalah proses terbentuknya tingkah laku baru sebagai hasil respons individu terhadap lingkungannya, dengan kata lain belajar adalah perubahan dalam tingkah laku dan cara seseorang berbuat dalam situasi tertentu. 
Pengertian pembelajaran tersebut dapat diartikan sebagai usaha kearah pencapaian tujuan melalui aktifitas orang lain atau membuat sesuatu untuk dikerjakan orang lain, berupa peningkatan minat, perhatian, kesenangan dan latar belakang peserta didik untuk meningkatkan kualitas peserta didik serta mengarah kepada pengembangan gaya hidup dimasa mendatang. Para ahli seperti Ambarita (2006:72) mengemukakan manajemen pembelajaran berarti kemampuan guru dalam mendayagunakan sumber daya yang ada, melalui kegiatan menciptakan dan mengembangkan kerja sama, sehingga terbentuk pembelajaran untuk mencapai tujuan pendidikan di kelas secara efektif dan efisien.

Pesantren sebagai lembaga pendidikan dan pengajaran Islam dimana didalamnya terjadi interaksi antara kyai atau ustadz sebagai guru dan para santri sebagai murid dengan mengambil tempat di masjid atau di halaman-halaman asrama (pondok) untuk mengaji dan membahas bukubuku teks ini lebih dikenal dengan sebutan kitab kuning, (Departemen Agama, 2003:3).

Dalam dunia pesantren, santri banyak diajari dengan berbagai ilmu agama seperti : fiqih, faroid, nahwu, șorof dan lain sebagainya. Tidak hanya itu santri juga diajari untuk berdisiplin dalam segala hal, baik dalam hal belajar, aktifitas olahraga dan dalam kegiatan beribadah, seperti penekan disiplin dalam salat berjamaah, dimana santri dituntut untuk mengikuti salat berjamaah dalam 5 waktu. Eman Sulaiman mengungkapkan bahwa "salat merupakan ibadah paripurna yang mamadukan olah pikir, olah gerak, dan olah rasa (sensibilitas), ketiganya terpadu secara harmonis. Salat pun merupakan kontemplasi dan riyadah (latihan) yang terintegrasi sempurna, saling melengkapi dari dimensi perilaku atau lisan (al bayan), respon motorik, rasionalitas (menempatkan diri secara proporsional ), dan kepekaan terhadap jati diri, kepekaan dan kehalusan untuk merasakan cinta dan kasih sayang Allah Swt" (Eman Sulaeman, 2002:7)

Manajemen pembelajaran adalah segala upaya yang dilakukan dalam mengelola pembelajaran di kelas dan guru sebagai manajer di dalam kelas memiliki aktifitas mencakup kegiatas merencanakan, melaksanakan dan penilaian hasil pembelajaran yang dikelolanya, (Haerana, 2016:24). Pengelolaan manajemen pembelajaran kitab kuning yang 
pertama, dalam merencanakan yaitu menyusun tujuan pembelajaran, kedua, dalam melaksanakan yaitu menghubungkan atau menggabungkan seluruh sumber daya pembelajaran dan motivasi santri untuk siap menerima materi pelajaran dalam mencapai tujuan secara efektif dan efesien dan ketiga melakukan penilaian hasil pembelajaran atau evaluasi yang dilaksanakan mencapai tujuan, sehingga dapat diketahui kemampuan santri tersebut dalam pemahaman AlQur'an maupun kitab kuning.

\section{METODE PENELITIAN}

Penelitian ini menggunakan penelitian kualitatif. Penelitian kualitatif merupakan suatu pendekatan dalam melakukan penelitian yang berorientasi pada fenomena atau gejala yang bersifat alami. Sifatnya mendasar dan naturalistis atau bersifat kealaman, serta tidak bisa dilakukan di laboratorium, melainkan di lapangan, oleh sebab itu sering disebut dengan naturalistic inquiry, atau field study.

Studi kasus di Pondok Pesantren Asy Syifa Saruni Pandeglang, dan objek penelitiannya adalah pembelajaran kitab kuning di Pondok pesantren Asy Syifa Saruni Pandeglang.

Sumber data meliputi: 1) Pimpinan Pondok Pesantren Asy Syifa Ustad Endang, 2) Dewan Pengajar Santri, Ustad. Aris Suhud dan Ustadzah Neli Amelia, 3) Rois Santri Putra, Muhammad Rizal dan Rois Santri Putri, Nurhasanah sebagai santri senior di Pondok Pesantren Asy Syifa Saruni Pandeglang. Dan Teknik Pengumpulan Data Meliputi: 1) Wawancara, 2) Observasi, 3) Dokumentasi.

Analisis data dilakukan dengan kategorisasi data penafsiran data. Adapun uji absah dta dilakukan dengan perpanjangan keikutsertaan, ketekunan pengamatan, triangulasi, cek teman sejawat, analisis kasus negatif, kecukupan referensi, uraian rinci dan auditing.

\section{HASIL DAN PEMBAHASAN}

Berdasarkan hasil observasi, wawancara dan dokumentasi yang ada di lapangan manajemen pembelajaran kitab kuning di Pondok Pesantren Asy Syifa Saruni Pandeglang adalah sebagai berikut. Perencanaan adalah suatu cara pemilihan dan penentuan langkahlangkah atau cara-cara yang dapat dilakukan dengan didasarkan pada 
kemampuan intelektual yang dimiliki sehingga menghasilkan suatu rancangan kerja di masa depan untuk mewujudkan pencapaian tujuan yang diinginkan. Perencanaan merupakan tahap awal dari semua kegiatan untuk itu penyusunannya harus mempertimbangkan berbagai aspek, sebab kualitas hasil atau pencapaian tujuan sangat bergantung pada kematangan perencanaan. Perencanaan proses pembelajaran terkait dengan penentuan langkah awal kegiatan sebelum pelaksanaan pembelajaran dilakukan (Haerana, 2016:35-38).

Perencanaan pembelajaran di pondok pesantren Asy Syifa berdasarkan pemikiran dan pemahaman kiyai mengenai jenjang pembelajaran kitab kuning karena tidak adanya RPP yang jelas di pondok pesantren salafiyah, perencanaan pembelajaran berakar pada kemampuan santrinya, jika santri tersebut masih awam dengan keilmuan pesantren apakah itu ilmu qur'an, maupun nahwu dan sharafnya makan santri tersebut akan diorientasikan mempelajari kitab-kitab pundamental/mendasar agar pemahamannya dapat tercapai dari kitab yang paling dasar. Begitu pula santri yang sudah senior dengan pemahaman kitabnya yang banyak serta kemampuan analisis serta hapalannya yang sudah bagus makan akan diorientasikan untuk mempelajari kitab-kitab dengan tingkatan yang lebih tinggi guna memperdalam keilmuannya. Untuk mengetahui kemampuan santri itu sejauh mana, kemampuan santri dalam mendalami ilmu al-Qur'an dapat dilihat dari pemahamannya terkait kitab-kitab yang telah dipelajarinya seperti hafalan nadhamnadham dan kefasihannya dalan membaca al-Qur'an. Menurut Mulyasa dikutip Haerana (2016:45), pada umumnya pelaksanaan pembelajaran mencakup tiga kegiatan, yakni pembukaan, pembentukan kompetensi dan penutup.

Pelaksanaan pembelajaran di pondok pesantren Asy Syifa secara garis besar terbagi menjadi dua, ada yang berdasarkan sistem klasikal (Ibtida/Tsanawi) ada juga yang dilaksanakan secara bersama-sama yang disesuaikan dengan kitab yang dipelajari. Pelaksanaan ini didasarkan pada sebuah kebutuhan serta kemampuan santri itu sendiri, oleh karena itu ada perbedaan proses pembelajaran. Sama halnya sistem pembelajaran di pondok pesantren lainnya, metode yang digunakan 
biasanya mengunakan metode bandongan pada pembelajaran kitab dan sorogan pada pembelajaran AlQur'an dan hampir semua pembelajaran yang dilakukan menggunakan pendekatan teacher centered atau terpusat pada sosok kyai atau pengajar di pesantren itu sendiri.

Tabel 1. Jadwal Pembelajaran Kitab Kuning

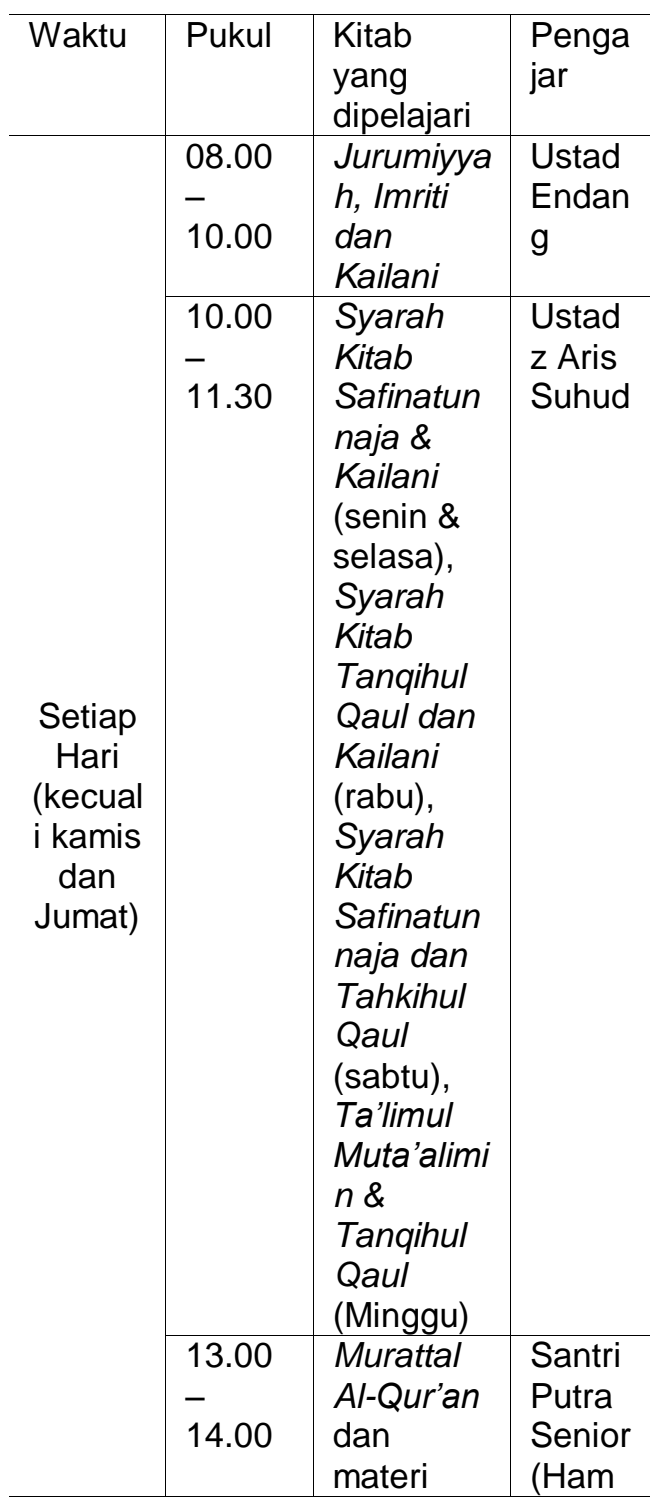

\begin{tabular}{|c|c|c|}
\hline & $\begin{array}{l}\text { ilmu } \\
\text { tajwid }\end{array}$ & $\begin{array}{l}\text { bali, } \\
\text { Rijal } \\
\text { dan } \\
\text { Mukhli } \\
\text { s) }\end{array}$ \\
\hline $\begin{array}{l}14.00 \\
- \\
15.30\end{array}$ & $\begin{array}{l}\text { Safinatun } \\
\text { naja, } \\
\text { Riyadush } \\
\text { Shalihin, } \\
\text { Aqidah } \\
\text { Awaliyyah }\end{array}$ & $\begin{array}{l}\text { Ustad } \\
\text { Endan } \\
\mathrm{g}\end{array}$ \\
\hline $\begin{array}{l}16.15 \\
- \\
17.15\end{array}$ & $\begin{array}{l}\text { Mujawwaj } \\
\text { Al-Qur'an }\end{array}$ & $\begin{array}{l}\text { Ustad } \\
\text { Endan } \\
\mathrm{g}\end{array}$ \\
\hline $\begin{array}{l}21.00 \\
- \\
22.00\end{array}$ & $\begin{array}{l}\text { Nihayah } \\
\text { Qaul } \\
\text { Mufidz }\end{array}$ & $\begin{array}{l}\text { Ustad } \\
\text { Endan } \\
\mathrm{g}\end{array}$ \\
\hline
\end{tabular}

Evaluasi dapat diartikan sebagai suatu kegiatan yang terencana untuk mengetahui keadaan suatu objek dengan menggunakan instrumen dan hasilnya dibandingkan dengan suatu tolak ukur untuk memperoleh suatu kesimpulan. Penilaian hasil pembelajaran merupakan kegiatan akhir yang dilakukan oleh guru terkait dengan proses belajar mengajar yang telah dilakukannya, (Haerana, 2016:75).

Pembelajaran sejatinya mampu menciptakan suasana yang kondusif dengan melakukan upaya perubahan kesadaran, menginspirasi para asatidz dan santri untuk bersinergi membawa kepada manajamen yang baik (Aat Royhatudin, Supardi, Juhji, 2020). Di kebanyakan pondok pesantren termasuk di pondok pesantren Asy Syifa berorientasi pada ketuntasan materi, satu kitab 
dipelajari secara terus menerus dan berulang ulang hingga pada akhirnya santri memahami isi dan kandungan dari kitab yang dipelajarinya tersebut. Namun ada beberapa pembelajaran juga yang menggunakan evaluasi secara komferhensif untuk mengkur ketercapaian dan pemahaman dari setiap bab yang dijarkan. Pada satu sisi memang tidak ada sebuah test untuk mengukur dalam ranah kognitif, namun semua pembelajaran di pesantren diorientasikan untuk bisa merubah yang berdampak pada ranah afektif dan psikomotorik seluruh santrinya yang mana pada akhirnya santri bisa mengamalkan apa yang dia pelajari selama belajar di pondok pesantren dan kemudian bisa mengarahkan mereka menjadi sosoksosok yang shalih/shalihah ilmu yang didapat akan senantiasa berguna untuk umat.

Evaluasi dari pembelajaran kitab kuning yang di ajarkan di pondok pesantren Asy Syifa ini menggunakan sistem sorogan, bandongan dan hafalan tersebut umumnya pembelajaran yang ada di pondok psantren salafiyah, karena pada dasarnya santri dilatih untuk mengembangkan keilmuannya yang telah disampaikan oleh kiyai atau ustadz. Sistem sorogan untuk pembelajaran Al-Qur'an dapat dilakukan dengan face to face atau muajahah untuk mengetahui kelebihan dan kekurangan dari santri tersebut dalam pembacaan Al-Quran baik itu dari segi pelafalan, makharijul hurufnya hingga sifatul hurufnya. Sistem hafalan untuk pengajian atau pembelajaran kitab kuning iu sendiri seperti dalam pemahaman kitab jurumiah, imriti, yaqulu dengan nadhoman yang dilafalkan setiap kali sebelum pembelajaran itu berlangsung sambil menunggu pengajar datang santri melafalkannya sekitar 5-20 menit, itupun untuk mereview santri sebagai hasil dari pembelajaran kitab kuning yang dipelajarinya. Bandongan disini dapat dilakukan oleh santri senior maupun oleh ustadz/ustadzah, kiyai disini memantau dalam keberlangsungan proses pembelajaran itu sendiri. Dengan cara seperti itu santri dapat menerapkan hasil yang diperoleh. Sorogan, bandongan dan hafalan disini sebagai tolak ukur dari evaluasi pembelajaran untuk para santri agar senantiasa ilmu yang didapatkannya itu sendiri bisa berdampak untuk kedepannya jika mereka sudah menjadi alumni dan dapat berguna untuk lingkungan sekitarnya. 
Perencanaan merupakan salah satu tugas yang sangat penting bagi guru. Adapun tujuan pembuatan perangkat pembelajaran tersebut adalah untuk memudahkan guru dalam melaksanakan pembelajaran sehingga hasil yang dicapai dapat maksimal. Pondok pesantren Asy Syifa sebagai salah satu pesantren bercorak salafiyah yang masih eksis dan menjaga tradisi pesantrennya tentunya memiliki corak dan kultur pendidikan tersendiri, pesantren salafiyah yang cenderung berpola tradisional dan mono manajerial dan bergatung pada otoritas serba kyai termasuk dalam merencanakan dan merumuskan pembelajaran di pondok pesantren.

Dunia pesantren lebih diidentikan dengan cara dan metode pembelajaran yang monoton apalagi materi pembelajarannya hanya ilmuilmu agama melalui kitab kuning (klasik). Sebagai barometernya seorang santri dapat diukur dari kemampuannya dalam membaca dan memahami kitab-kitab tersebut. Karena itu, metode sorogan, wetonan atau bandongan dan hafalan menjadi sangat dominan di pesantren (Royhatudin, 2018) Proses pembelajaran di pesantren merupakan suatu aktivitas yang bertujuan. Artinya proses pembelajaran tersebut dilakukan untuk mencapai tujuan tertentu yang telah dirumuskan sebelumnya. Selama ini penggambaran hasil belajar pada umumnya cenderung ke kemampuan yang bersifat kognitif dan hafalan semata, itu pun lebih banyaj berorientasi pada pengetahuan dan ditambah sedikit pemahaman, (Masyud, 2003: 96). Dalam pembelajaran kitab kuning di pondok pesantren Asy Syifa menggunakan metode pembelajaran khas di pesantren seperti bandongan, wetonan, muhadatsah, muhafadhah, dan lainnya. Pembelajaran dengan metode khas pesantren di pondok pesantren Asy Syifa yang pada awalnya hanya berpusat kepada kyai saja, sekarang sudah dibagi ke beberapa ustadz/ustadzah dengan berdasarkan kelas masing-masing yaitu sesuai dengan jenjang kajian kitab kuningnya dan semua santri diwajibkan mengikuti pembelajaran kitab kuning tersebut. Semua yang dilakukan ini dimaksudkan untuk memberikan pengetahuan dan pengembangan para santri dalam memahami dan mendalami kitab kuning. Pembelajaran kitab kuning di pesantren seakan menjadi sebuah tradisi yang sangat melekat dan tidak 
bisa dipisahkan dari pesantren, pembelajaran kitab kuning di pesantren menjadi sebuah pembeda antara pendidikan di pesantren dengan lembaga pendidikan lainnya.

Menurut Rahman (2012) dalam jurnal yang berjudul manajemen pembelajaran kitab kuning, bahwa dalam keseluruhan proses pendidikan di pesantren, kegiatan pembelajaran dalam rangka mencapai prestasi dan transfer ilmu pengetahuan dan moral termasuk kegiatan teknis operasional yang paling penting. Hal ini berarti berhasil tidaknya pencapaian tujuan pendidikan bergantung pada bagaimana aktivitas belajar-mengajar dilaksanakan atau dalam istilah pesantren dikenal dengan ta'lim wa ta'allum. Setidaknya ada tiga fungsi pokok ta'lim wa ta'allum di pesantren. Pertama, transmisi ilmu pengetahuan Islam. Pengetahuan Islam dimaksud tentunya tidak hanya meliputi pengetahuan agama, tetapi juga mencakup seluruh pengetahuan yang ada. Kedua, pemeliharaan ajaran Islam. Ketiga, pembinaan calon-calon ulama.

\section{SIMPULAN}

Berdasarkan penelitian yang dilakukan di Pondok pesantren Asy Syifa Saruni Pandeglang, maka dapat ditarik kesimpulan sebagai berikut. Manajemen Pembelajaran kitab kuning di Pondok Pesantren Asy Syifa memiliki keunikan tersendiri selain dari pada penggunaan metode khas pesantren (tradisional) juga dikarenakan banyaknya keilmuan yang diajarkan di pondok pesantren.

Perencanaan pembelajaran di pondok pesantren Asy Syifa ini berdasarkan pemikiran dan pemahaman kiyai serta tidak adanya RPP yang jelas, perencanaan pembelajaran berakar pada kemampuan santrinya itu sendiri, jika santri tersebut masih awam keilmuan pesantrennya dalam pembelajaran kitab maka disesuaikan dengan diorientasikan mempelajari kitab-kitab yang mendasar. Di pesantren ini menggunakan sistem bandongan, sorogan dan nadhaman dalam pelaksanaan pembelajaran kitab kuning maupun Al-Qur'an sesuai dengan kebutuhan dan orientasi pembelajaran itu sendiri. Proses pembelajaran di pondok pesantren Asy Syifa dilakukan oleh seluruh dewan kyai dan ustadz dan pada proses-proses tertentu juga melibatkan para santri senior untuk menjadi tutor dalam pengembangan santri. Evaluasi pembelarajaran kitab kuning di pondok pesantren Asy Syifa 
berorientasi pada ketuntasan materi, satu kitab dipelajari secara terus menerus dan berulang ulang hingga pada akhirnya santri memahami isi dan kandungan dari kitab yang dipelajarinya tersebut. Ada beberapa pembelajaran yang menggunakan evaluasi secara konferhensif untuk mengukur ketercapaian dan pemahaman dari setiap bab yang dijarkan. Evaluasi dari para santrinya itu sendiri bisa mengamalkan apa yang dipelajari selama belajar di pondok pesantren dan kemudian bisa mengarahkan mereka menjadi sosoksosok yang shalih/shalihah yang nantinya dapat senantiasa berguna untuk umat.

\section{DAFTAR PUSTAKA}

Aat Royhatudin, Supardi, Juhji. Transformational Leadership Style in Implementing Madrasa Based Management. Tarbawi, 6980.

Badrudin. (2013). Dasar-dasar Manajemen. Bandung: Alfabeta.

Departemen Agama, (2003) Pola Pengembangan Pondok Pesantren, Jakarta: Departemen Agama RI.

Dhofier, Zamakhsyari (2011) Tradisi Pesantren Studi Tentang Pandangan Hidup Kiyai Jakarta: LP3ES.
Haerana, (2016) Manajemen Pembelajaran Berbasis Standar Proses Pendidikan Teori Dan Aplikasinya. Yogyakarta: Media Akademi.

Maharani, (2016) Manajemen Pembelajaran Pondok Pesantren

Madjid, Nurholis. 1997. Bilik-bilik Pesantren Sebuah Potret Perjalanan. Jakarta: Paramadina.

Masyhud, Sulthon dkk, (2003) Manajemen Pondok Pesantren, Diva Pustaka : Jakarta.

Rahman, Fityan Indi (2012) Manajemen Pembelajaran Kitab Kuning di Pondok Pesantren AlFalah Putera Banjarbaru dan Pondok Pesantren Raudhatul Amin Amuntai. Tesis, Pasca Sarjana. (idr.iainantasari.ac.id/2861/1/BAB\%20I.p df) diakses pada 14 Maret

Royhatudin, A. (2018). PENGUATAN NILAI-NILAI PENDIDIKAN ISLAM. Jurnal Pendidikan Agama Islam, XV(II), 184-198.

Sulaiman, Eman. 2002. Simbol-simbol Shalat. Bandung: Madani Prima. 